\title{
Effect of Striga Trap Crops and Nitrogen Fertilizer Application on Yield and Yield Related Traits of Sorghum [Sorghum bicolor (L.) Moench] at Fedis District, Eastern Ethiopia
}

\author{
Fikadu Tadesse ${ }^{1 *}$, Tamado Tana2 ${ }^{2}$, Jemal Abdulahi², Fuad Abduselam ${ }^{1}$ \\ ${ }^{1}$ Fedis Agricultural Research Center, Cereal Research Case Team, Harar, Ethiopia \\ ${ }^{2}$ School of Plant Sciences, Collage of Agriculture and Environmental Sciences, Haramaya University, Haramaya, Ethiopia \\ Email: *Fiktgute@gmail.com
}

How to cite this paper: Tadesse, F., Tana, T., Abdulahi, J. and Abduselam, F. (2018) Effect of Striga Trap Crops and Nitrogen Fertilizer Application on Yield and Yield Related Traits of Sorghum [Sorghum bicolor (L.) Moench] at Fedis District, Eastern Ethiopia. Open Access Library Journal, 5: e3978.

https://doi.org/10.4236/oalib.1103978

Received: September 26, 2017

Accepted: April 16, 2018

Published: April 19, 2018

Copyright $\odot 2018$ by authors and Open Access Library Inc.

This work is licensed under the Creative Commons Attribution International License (CC BY 4.0).

http://creativecommons.org/licenses/by/4.0/

\begin{abstract}
Striga causes a serious threat to successful cultivation of sorghum in areas of low and erratic rainfall and poor soil fertility. Therefore, to reduce yield losses and severity of Striga, a field experiment was conducted during the cropping season of 2015 on heavily Striga-infested field in Fedis District, Boko site to determine the effect of trap crops (cowpea, soybean, desmodium, control) and $\mathrm{N}$ fertilizer rates $\left(0,46,92\right.$ and $\left.138 \mathrm{~kg} \mathrm{~N} \mathrm{ha}^{-1}\right)$ on management of Striga, yield related traits and yield of sorghum. The experiment was laid out in a factorial arrangement in a randomized complete block design (RCBD) with three replications. Moreover, LAI, plant height, head weight plot $^{-1}$ and aboveground dry biomass yield of sorghum were significantly $(\mathrm{P}<0.05)$ increased by $4 \%$, $9 \%, 28 \%$ and $33 \%$, respectively, by use of cowpea as a trap crop over the control. Likewise use of cowpea as a trap crop significantly $(\mathrm{P}<0.01)$ increased kernel weight head ${ }^{-1}$ by $6 \%$ and grain yield by $23 \%$ over the control. Similarly, the main effect of nitrogen showed that increased nitrogen rate up to $46 \mathrm{~kg}$ $\mathrm{ha}^{-1}$ significantly reduced Striga number at sorghum emergence by about $49.8 \%$ over control. Days to heading, flowering and maturity on sorghum were significantly $(\mathrm{P}<0.01)$ affected by nitrogen fertilizer rate and the application of $46 \mathrm{~kg} \mathrm{~N} \mathrm{ha}^{-1}$ resulted in earlier heading by $6 \%$ over138 $\mathrm{kg} \mathrm{N} \mathrm{ha}^{-1}$. Application of $138 \mathrm{~kg} \mathrm{~N} \mathrm{ha}^{-1}$ delayed days to flowering by 6 days over $46 \mathrm{~kg} \mathrm{~N}$ $\mathrm{ha}^{-1}$. Plots that received $46 \mathrm{~kg} \mathrm{~N} \mathrm{ha}^{-1}$ attained $90 \%$ physiological maturity earlier (127.1 days) than other treatments. Application of $46 \mathrm{~kg} \mathrm{~N} \mathrm{ha}^{-1}$ significantly increased kernel weight head ${ }^{-1}$ by $12 \%$ and aboveground dry biomass yield by $33 \%$ over the control. LAI and grain yield were significantly $(\mathrm{p}<0.01)$ affected by main effect of $\mathrm{N}$ where the highest (2.387) leaf area index and the
\end{abstract}


highest $\left(3116 \mathrm{~kg} \mathrm{ha}^{-1}\right)$ grain yield were obtained with $46 \mathrm{~kg} \mathrm{~N} \mathrm{ha}^{-1}$.

\section{Subject Areas}

Agricultural Science

\section{Keywords}

Cowpea, Desmodium, Nitrogen Fertilizer, Sorghum, Soybean

\section{Introduction}

Sorghum is the most important staple crop in Ethiopia. It was grown on 1, $831,600.45$ ha with a total production of $4,339,134.261$ tons [1]. The crop has been cultivated for thousands of years and hence indigenous knowledge based sorghum classification and naming has a long tradition. The crop has coexisted with the people for millennium and sorghum production is predominantly based on farmers' varieties as cited by [2].

In East Hararghe Zone, out of the total grain cropped area of 253,816.82 ha, cereals accounted for about $84 \%$ (214,061.59 ha) of which sorghum accounted for the lion's share of about $56 \%(119,262.36 \mathrm{ha})$ of the totally annually cropped land in 2014/15 cropping season [1]. In this Zone, sorghum is first important food crop and element of the local diet. It is produced not only for its food grains but also for its use as a source of animal feed and construction material, which is grown mainly under rain-fed condition.

The livelihoods of millions of subsistence farmers depend on sorghum production. However, its productivity in Ethiopia is low at about 2.3690 tons ha ${ }^{-1}$ [1].The sorghum yield in East Hararghe Zone is currently 2 tons ha ${ }^{-1}$ [1], which is far below the yield potential of the crop, 3 to $6 \mathrm{t} \mathrm{ha}^{-1}$ as indicated by [3]. This is attributed to a number of abiotic and biotic stresses. Yield reducing factors include low soil fertility (nutrient deficiency), drought, moisture stress, Striga, stem borers and shoot fly and various diseases [4]. Although these constraints cause a significant loss of grain, the level of losses varies from region to region. In Ethiopia, Striga is a major production constraint in most sorghum producing areas. The weed limits the productivity of the crop by allelopathy, competition for nutrients and moisture and limiting the expression of the full genetic potential of sorghum plants.

During stress situation, the menace of Striga is heavy as compared to normal season and such incidence was noticed in Fedis Districts of East Hararghe Zone in drought years. Although several management methods have been tried and developed against this parasitic weed in other parts of the world, there is still no effective management method applied in Fedis district though there is little use of tolerant varieties, chemical fertilizers and tied ridging which needs to be promoted in the future. Therefore, the current study was carried out to investigate 
the role of legumes as trap crops and application of inorganic nitrogen fertilizer in suppressing the menace of Striga in sorghum production.

Therefore, the specific objective of this study was to assess the effect of trap crops and nitrogen fertilizer rates on Striga incidence, yield related traits and yield of sorghum at Fedis district, eastern Ethiopia.

\section{Materials and Methods}

\subsection{Description of the Experimental Site}

The experiment was conducted at Fedis Agricultural Research Center (FARC) experimental station (Boko site) in 2015 cropping season on previously Striga infested area. The area is $24 \mathrm{~km}$ away from Harar town in the southern direction. The experimental site is located at a latitude of $9^{\circ} 07^{\prime} 51.6^{\prime \prime} \mathrm{N}$ and longitude of $42^{\circ} 04^{\prime} 24.3^{\prime \prime} \mathrm{E}$ at average altitude of 1702 meters above sea level (m.a.s.l.).

\subsection{Description of Experimental Materials}

Improved lowland sorghum variety "Teshale" was used as a test crop. The variety has been released by Melkassa Agricultural Research Center in 2002 and adaptation trial was done in the year 2011 at the study area by Fedis Agricultural Research Center. It is an early maturing sorghum variety but is sensitive to Striga infestation. It requires $600-900 \mathrm{~mm}$ rainfall and grows at an altitude of 1450 1850 meters above sea level (m.a.s.l.). The variety needs 75 days to heading and 123 days to reach maturity [5].

The trap crops used were cowpea (Vigna unguiculata) varietyIT93 KD 596 (Sewinet) released in 2009 by Pawe Agricultural Research Center and soybean (Glycine max) varietyAwassa-95 (G2261) released in 2005 by Awassa Agricultural Research Center, Desmodium (Desmodium intortum) obtained from Fedis Agricultural Research Center.Urea (46\% N) was used as a source of nitrogen, while triple super phosphate (TSP) $\left(46 \% \mathrm{P}_{2} \mathrm{O}_{5}\right)$ which was obtained from Haramaya University was used as source of phosphorus.

\subsection{Treatments and Experimental Design}

The treatment consisted of four nitrogen levels $\left(0,46,92\right.$ and $\left.138 \mathrm{~kg} \mathrm{~N} \mathrm{ha}^{-1}\right)$ and three trap crops (cowpea, soybean and Desmodium) with control. Sorghum variety Teshalewas used as test crop. The experiment was laid out in a factorial arrangement in a randomized complete block design (RCBD) with three replications and 16 treatment combinations consisting of two factors. Each plot had 5 rows of sorghum with a gross plot size of $5 \times 0.75 \mathrm{~m}(3.75 \mathrm{~m})$ width and length of the plot was $3 \mathrm{~m}$ and with total plot area of $11.25 \mathrm{~m}^{2}$. The net plot size was $2.25 \times 2.4 \mathrm{~m}$. The necessary data were collected from middle 3 rows. Plants were spaced at $75 \mathrm{~cm}$ and $15 \mathrm{~cm}$ between rows and plants, respectively. Plots and blocks were separated by $1 \mathrm{~m}$ distance.

Phosphate fertilizer in the form of triple supper phosphate (TSP) was applied uniformly at planting at the rate of $46 \mathrm{~kg} \mathrm{ha}^{-1} \mathrm{P}_{2} \mathrm{O}_{5}$ and different levels of the ni- 
trogen, in the form of urea, was applied in two splits i.e. half at the time of sowing and the remaining half $\mathrm{N}$ was top-dressed just before heading. All weeds except Striga were weeded manually and other agronomic practices were done as per the recommendation for sorghum. Harvesting was done at harvest maturity for sorghum. The harvested produce was sun-dried for 10 days and hand threshed and simultaneously winnowing was done.

\subsection{Data Collection}

\section{Sorghum Component}

Data collected for phenology and growth and yield components and yield were: Days to $50 \%$ emergence, Days to $50 \%$ flowering, days to maturity, Plant height, leaf area index, Panicle length, Crop stand count, Thousand kernel weights (g), Grain yield $\left(\mathrm{kg} \mathrm{ha}^{-1}\right)$, Aboveground dry biomass yield $\left(\mathrm{kg} \mathrm{ha}^{-1}\right)$, Harvest Index.

\subsection{Statistical Data Analysis}

Analysis of variance was carried out using GenStat discovery $15^{\text {th }}$ edition software [6] for the parameters studied following the standard procedures outlined by [7]. When the treatment effects were found to be significant, the means were separated using the Fisher's Protected Least Significant Difference (LSD) test at $5 \%$ level of probability.

\section{Result and Discussion}

\subsection{Climatic Condition of the Study Area}

During 2015, a total rainfall of $724.5 \mathrm{~mm}$ was received which was $158.2 \mathrm{~mm}$ less than the average of four years and in months of experimentation from sowing of trap crops to sorghum harvest the area received $565.8 \mathrm{~mm}$ of rainfall, which was 90.45 less than the normal (previous four years) (Figure 1). However the crop experienced more rainfall in the months of May $(161.7 \mathrm{~mm})$ and June $(132.3$ $\mathrm{mm}$ ) than the normal years.

The monthly total rainfall, maximum and minimum temperature and relative humidity of Fedis district, Boko site in 2015 is shown here under (Figure 1).

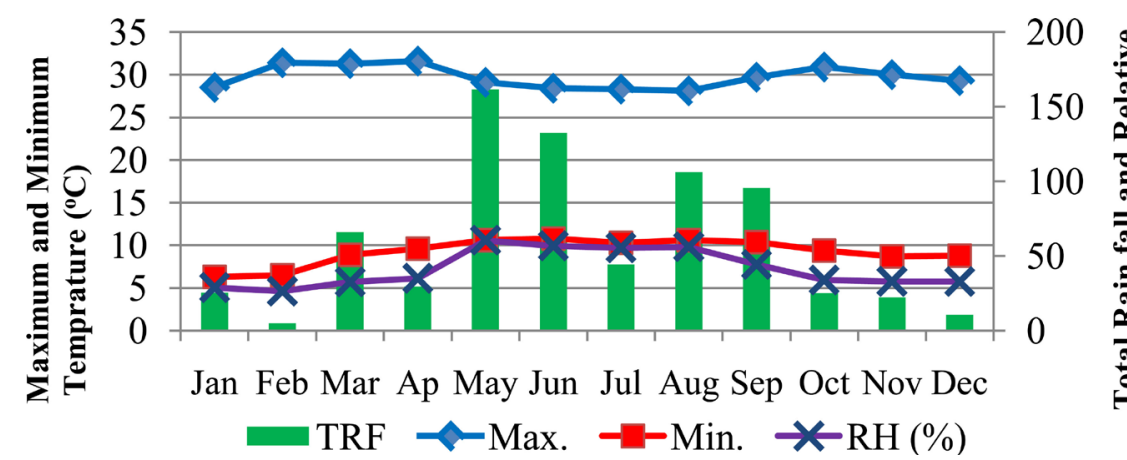

Figure 1. Monthly total rainfall $(\mathrm{mm})$, maximum and minimum air temperature $\left({ }^{\circ} \mathrm{C}\right)$ and relative humidity (\%) of Fedis district, Boko site in 2015. 


\subsection{Physico-Chemical Properties of Soil before Sowing}

Selected Physico-chemical properties of the experimental soil were estimated and presented (Table 1). The textural class of the soil was clay loam, with the proportion of $29 \%$ sand, $36 \%$ clay and $35 \%$ silt, which was ideal for sorghum production according to [8]. The $\mathrm{pH}$ value was 8.05 and according to the rating of [9], it was moderately alkaline, but it was within the optimum range for sorghum production, i.e. 5.5 to 8.5 [8]. Organic carbon of the soil was $1.4 \%$, which was low according to the rating of [9]. Hence, amending the soil with organic fertilizers is important for enhancing soil fertility to reduce the Striga infestation and increase sorghum yield.

The available $\mathrm{P}$ content $\left(5.45 \mathrm{mg} \mathrm{kg}^{-1}\right)$ of the experimental site was low according to classification by [10] where available $\mathrm{P}$ content below $5 \mathrm{mg} \mathrm{kg}^{-1}$ is very low; between 5 and $9 \mathrm{mg} \mathrm{kg}^{-1}$ is low; between 10 and $17 \mathrm{mg} \mathrm{kg}^{-1}$ is medium; between 18 and $25 \mathrm{mg} \mathrm{kg}^{-1}$ is high and greater than $25 \mathrm{mg} \mathrm{kg}^{-1}$ is very high. According to the rating of [9], the total $\mathrm{N}$ content of the soil (0.11\%) is low, which would limit sorghum production. Therefore, the soils need amendment with nitrogen and/or organic fertilizers. With regards to the exchangeable potassium [11] described soils, $<0.26,0.26-0.51,0.51-0.77$ and $>0.77\left[\left(\mathrm{cmol}(+) \mathrm{kg}^{-1}\right)\right]$ as very low, low, medium, and high, respectively. Thus, the exchangeable $\mathrm{K}[0.92$ cmol $\left.\left.(+) \mathrm{kg}^{-1}\right)\right]$ of the experimental soil was high. Cation exchange capacity (CEC) of experimental site was $35.2 \mathrm{cmol}(+) \mathrm{kg}^{-1}$ high, according to [12] very low $<5$, low 5 - 15, medium 15 - 25, high 25 - 40 and very high $>40$.

Although sorghum can produce best on deep, fertile, well-drained loamy soils, it is much more tolerant of shallow soil and drought conditions than maize [13]. Sorghum can be grown successfully on clay, clay loam, or sandy loam soils.

Table 1. Selected physico-chemical properties of the experimental soils at fedis (boko site) in 2015 cropping season before planting.

\begin{tabular}{cccc}
\hline Properties & Values & Rating & References \\
\hline $\begin{array}{c}\text { Physical properties } \\
\text { Particle size distribution }\end{array}$ & & & \\
Sand (\%) & 29 & & \\
Silt (\%) & 35 & & \\
Clay (\%) & 36 & & \\
Soil texture & Clay loam & & Tekalign Tadesse (1991) \\
Chemical properties & & & Tekalign Tadesse (1991) \\
Organic carbon (\%) & 1.4 & Low & Cottenie (1980) \\
Total nitrogen (\%) & 0.11 & Low & Berhanu Debele (1980) \\
Available phosphorus (mgkg $\left.{ }^{-1}\right)$ & 5.45 & Low & Tekalign Tadesse (1991) \\
Exchangeable potassium (c mol (+) $\mathrm{kg}^{-1}$ ) & 0.92 & High & \\
Soil pH (1:2.5 soil:water) & 8.05 & Strongly alkaline & \\
\hline
\end{tabular}


Therefore, it can be concluded the soil of the experimental site is ideal for sorghum production except its limitation in the availability of phosphorus, total nitrogen, and organic carbon.

\subsection{Phenological and Growth Parameters}

\subsubsection{Days to $50 \%$ Emergence}

The analysis of variance revealed that the main effects of trap crops significantly $(\mathrm{P}<0.05)$ influenced days to $50 \%$ emergence of sorghum, unlike the nitrogen and interaction effects which had non-significant effect. Though no remarkable variation was observed among the trap crops for emergence of sorghum, it took six days under Desmodium and six and half days under cowpea as compared to fallow which took seven days (Table 2). This relatively earlier emergence of sorghum treated than the control in plots might be due to under cultivation of trap crops for germination to occur that lead to better emergence of the crop.

\subsubsection{Days to Heading}

The analysis of variance (ANOVA) revealed that the main effect of nitrogen highly and significantly $(\mathrm{P}<0.01)$ influenced days to $50 \%$ heading of sorghum, while the main effect of the trap crops and the interaction effect were not significant. Increasing the rate of nitrogen from 46 to $138 \mathrm{~kg} \mathrm{ha}^{-1}$ prolonged the days required for $50 \%$ headings. Thus, the longest days to heading (82 days) was observed with the use of rate of $138 \mathrm{~kg} \mathrm{~N} \mathrm{ha}^{-1}$ (Table 2). Sorghum plants grown under treatment that received the higher nitrogen rates $\left(138 \mathrm{~kg} \mathrm{ha}^{-1}\right)$ showed delayed heading by about $6 \%$ in days than plants grown under $46 \mathrm{~kg} \mathrm{~N} \mathrm{ha}^{-1}$ fertilizers.

Table 2. Main effect of trap crops and nitrogen application on phenological parameters of sorghum at fedis in 2015 cropping season.

\begin{tabular}{cccc}
\hline Treatment & Days To Emergence & Days To Heading & Days To Flowering \\
\hline Nitrogen $\left(\mathrm{kg} \mathrm{ha}^{-1}\right)$ & & $78.08^{\mathrm{c}}$ & $83.25^{\mathrm{bc}}$ \\
0 & 6.75 & $77.33^{\mathrm{c}}$ & $82.50^{\mathrm{c}}$ \\
46 & 6.67 & $80.83^{\mathrm{b}}$ & $85.08^{\mathrm{b}}$ \\
92 & 6.33 & $82.08^{\mathrm{a}}$ & $87.67^{\mathrm{a}}$ \\
138 & 6.58 & 0.961 & 2.125 \\
LSD (0.05) & $\mathrm{NS}$ & & 84.50 \\
Trap Crop & & 89.25 & 84.33 \\
Fallow & $6.92^{\mathrm{a}}$ & 79.25 & 85.08 \\
Cowpea & $6.58^{\mathrm{ab}}$ & 79.67 & 84.58 \\
Soybean & $6.75^{\mathrm{a}}$ & 80.17 & $\mathrm{NS}$ \\
Desmodium & $6.08^{\mathrm{b}}$ & $\mathrm{NS}$ & 3.0 \\
LSD (0.05) & 0.56 & 1.4 & \\
CV (\%) & 10.3 &
\end{tabular}

Means followed by the same letter(s) within a column are not significantly different at $\mathrm{P}=0.05$. 
This might have been attributed to the synergic effects of the $\mathrm{N}$ fertilizers in promoting cell growth and prolonged vegetative growth. The present result was in line with that of [14] who reported that application of $\mathrm{N}$ fertilizer promoted vegetative growth, leading to prolonged days to heading of sorghum.

\subsubsection{Days to Flowering}

Days to flowering were highly and significantly $(\mathrm{P}<0.01)$ influenced by the main effect of nitrogen but the main effects of trap crops and interactions were not significant. So with application of nitrogen at $46 \mathrm{~kg} \mathrm{~N} \mathrm{ha}^{-1}$ sorghum flowered earlier (82.5 days). But as level of $\mathrm{N}$ increased across the treatments from 46 to $138 \mathrm{~kg} \mathrm{~N} \mathrm{ha}^{-1}$, it resulted in delayed flowering (Table 3). The result indicated six days of earlier flowering of sorghum by application of $46 \mathrm{~kg} \mathrm{~N} \mathrm{ha}^{-1}$ over application of $138 \mathrm{~kg} \mathrm{~N} \mathrm{ha}^{-1}$. This result was consistent with the finding of [15] [16] who reported that higher $\mathrm{N}$ levels resulted in delayed leaf senescence, sustained leaf photosynthesis and extended days to flowering of sorghum. Days to flowering for the variety Teshale to be 71 days at Fedis with the use of $46 \mathrm{~kg} \mathrm{~N} \mathrm{ha}^{-1}$ also reported by [17]. But, this result gave 82 days, which might be due to difference in climatic condition of the cropping season since such phenological parameters are temperature dependent.

\subsubsection{Days to Maturity}

Days to maturity was highly and significantly $(\mathrm{P}<0.01)$ influenced by the main effect of nitrogen but the main effect of trap crops and interaction did not significantly affect days to $90 \%$ physiological maturity of sorghum. Application of $46 \mathrm{~kg} \mathrm{~N} \mathrm{ha}^{-1}$ resulted in the earliest (127.1 days) days to $90 \%$ physiological maturity of sorghum (Table 2). Though there was no significant differences between plots receiving $138 \mathrm{~kg} \mathrm{~N} \mathrm{ha}^{-1}$ (128.5 days) and $92 \mathrm{~kg} \mathrm{~N} \mathrm{ha}^{-1}$ (128.8 days), plots that received $46 \mathrm{~kg} \mathrm{~N} \mathrm{ha}^{-1}$ attained its $90 \%$ physiological maturity earlier (127.1 days). The prolonged time to reach maturity at higher rates of nitrogen might be attributed to the increase in leaf area duration, increased vegetative growth and increased light use efficiency.

Similarly, [18] found that higher $\mathrm{N}$ rates delayed maturity in sorghum than the control plots. This was in line with the findings of [19] who reported that nitrogen promotes vegetative and lush growth thereby delaying plant maturity.

\subsubsection{Plant Height}

Use of trap crops for Striga management showed significant $(\mathrm{P}<0.05)$ effect on sorghum plant height where use of cowpea as trap crop recorded the maximum plant height $(142.2 \mathrm{~cm})$ followed by soybean $(136.8 \mathrm{~cm})$. Significantly minimum $(128.7 \mathrm{~cm})$ plant height of sorghum was recorded in fallow $(128.7 \mathrm{~cm})$ (Table 3). However, the main effect of nitrogen and the interaction effect did not significantly influence sorghum plant height.

The use of cowpea as trap crop enhanced plant height by about $9 \%$ over the control, which might be due to higher root exudates production or stimulant concentration in case of cowpea that might have less number of Striga which, 
Table 3. Main effects of trap crops and nitrogen fertilizer application on growth parameters of sorghum at Fedis in 2015 cropping season.

\begin{tabular}{cccc}
\hline Treatment & PH & DPHM & LAI \\
\hline Nitrogen $\left(\mathrm{kg} \mathrm{ha}^{-1}\right)$ & & & \\
0 & 131.0 & $131.9^{\mathrm{a}}$ & $2.1^{\mathrm{c}}$ \\
46 & 135.3 & $127.1^{\mathrm{b}}$ & $2.4^{\mathrm{b}}$ \\
92 & 139.7 & $128.8^{\mathrm{b}}$ & $2.6^{\mathrm{a}}$ \\
138 & 137.8 & $128.5^{\mathrm{b}}$ & $2.6^{\mathrm{a}}$ \\
LSD (0.05) & $\mathrm{NS}$ & 1.963 & 0.114 \\
Trap Crop & & & \\
Fallow & $128.7^{\mathrm{b}}$ & 129.5 & $2.4^{\mathrm{b}}$ \\
Cowpea & $142.2^{\mathrm{a}}$ & 128.6 & $2.6^{\mathrm{a}}$ \\
Soybean & $136.8^{\mathrm{ab}}$ & 128.8 & $2.4^{\mathrm{b}}$ \\
Desmodium & $136.0^{\mathrm{ab}}$ & 129.4 & $2.2^{\mathrm{c}}$ \\
LSD (0.05) & 9.22 & $\mathrm{NS}$ & 0.11 \\
CV (\%) & 8.1 & 1.8 & $5.7^{\mathrm{b}}$ \\
\hline
\end{tabular}

Means followed by the same letter(s) within a column are not significantly different at $\mathrm{P}=0.05, \mathrm{PH}=$ plant height, DPHM = days to physiological maturity, LAI = leaf area index.

reduces plant height. This may be attributed to more Striga population in fallow treatment. Further, Striga after being established on the host root obtains water and nutrients from the host as the xylem of the parasite and host are connected. This might have resulted in strong competition of Striga with the crop for nutrients, moisture and space. Similar findings by [20] noticed that during Striga infestation there was reduced sorghum plant height and weight by $22 \%$ and $25 \%$ at 38 days after sowing and by $34 \%$ and $36 \%$ at 64 days after sowing, respectively.

\subsubsection{Leaf Area Index}

The main effect of nitrogen and trap crops significantly $(\mathrm{P}<0.05)$ influenced leaf area index of sorghum at 60 days after sowing unlike the interaction effect, which was not significant. The leaf area index was significantly higher (2.631) with the application of $138 \mathrm{~kg} \mathrm{~N} \mathrm{ha}^{-1}$ and (2.55) at $92 \mathrm{~kg} \mathrm{~N} \mathrm{ha}^{-1}$, while the lowest (2.089) leaf area index was recorded for the control (Table 3). Similarly, significant difference in leaf area index was also recorded between $46 \mathrm{~kg} \mathrm{~N}^{-1}(2.387)$ and the control (no N).

However, these rates significantly enhanced leaf area index over nil, the results depicted that at 60 days after sowing the optimal leaf area index was already attained at $46 \mathrm{~kg} \mathrm{~N} \mathrm{ha}^{-1}$. This result is in agreement with that of [21] who reported that at 55 days Striga infested plants of sorghum had significantly less shoot and root biomass and had significantly smaller leaf area than the sorghum plants in the uninfected control treatment.

The increase in LAI with increased $\mathrm{N}$ levels might be due to efficient use of 
nitrogen for vegetative growth by sorghum crop. In line with this result, [22] reported that the leaf area index of sorghum increased by 5.0\%, 9.5\% and 20.8\% over the control at 50,100 and $150 \mathrm{~kg} \mathrm{ha}^{-1}$ nitrogen fertilizations, respectively. Supporting evidences of the positive effects of nitrogen application on the leaf area index were also reported by [23] [24] where they observed significant increase in leaf area index of sorghum with increase of nitrogen fertilizer from 43 $129 \mathrm{~kg} \mathrm{ha}^{-1}$.

Similarly, the use of cowpea as trap crop increased leaf area index by about $4 \%$ over the control. But the use of soybean as trap crop had no significant difference from non-use of trap crop and use of Desmodium also did not have advantage over non-use of trap crop (Table 3). So the use of cowpeaas trap crop might be related with least number of Striga, which could result in increase in leaf area of sorghum. This result was in agreement with the study of [25] who reported that at 55 days infested plants of sorghum plant had significantly less shoot and root biomass and significantly smaller leaf area than the sorghum plants in the Striga uninfected control treatment.

\subsection{Yield Related Traits and Yield of Sorghum}

\subsubsection{Stand Count and Number of Panicle per Plot}

Neither the main effects nor the interaction effects of nitrogen and trap crops had significant influence on stand count of both after thinning, at harvest and number of panicles plot $^{-1}$. This might be due to the fact that stand count is not affected due to the soil fertility. Similarly, [25] reported non-significant effect of nitrogen fertilizer rates on stand count of sorghum. Non-significant effect of nitrogen fertilizer on stand count of sorghum also reported by [26].

\subsubsection{Head Weight per Plant}

The main effects of trap crops significantly $(\mathrm{P}<0.05)$ influenced the head weight plant $^{-1}$ but the main effect of nitrogen and interaction effect were not significant. The use of cowpea as trap crop increased head weight plant ${ }^{-1}(4999 \mathrm{~g})$ than the other trap crops including soybean (3861 g) and Desmodium (4009 g) (Table 4). Head weight plant ${ }^{-1}$ increased by $28 \%$ over control. The result might indicated cowpea had significant effect on reduction of Striga which increased head weight of sorghum through competing nutrients by releasing exudates as false host (trap crop).In line with this result, [27] reported higher root exudates production or stimulant concentration observed in case of cowpea as trap crop. The trap crop (cowpea) may cause suicidal germination of some of Striga seeds was also suggested by [28].

\subsubsection{Kernel Weight per Head}

The main effects of both nitrogen and trap crops highly and significantly $(\mathrm{P}<$ 0.01 ) influenced the kernel weight head ${ }^{-1}$ while the interaction effect was not significant. The highest kernel weight $(71.58 \mathrm{~g})$ per head was obtained at nitrogen fertilization level of $46 \mathrm{~kg} \mathrm{ha}^{-1}$ and the lowest (62.92 g) at nil rate of nitrogen 
Table 4. Main effects of trap crops and nitrogen fertilizer application on yield components of sorghum at Fedis in 2015 cropping season.

\begin{tabular}{cccccc}
\hline Treatment & SCH $\left(\mathrm{ha}^{-1}\right)$ & TKW (g) & KWH (g) & NPP $^{-1}$ & HWP $^{-1}(\mathrm{~g})$ \\
\hline Nitrogen $\left(\mathrm{kg} \mathrm{ha}^{-1}\right)$ & & & & & \\
0 & 75,037 & 23.00 & $62.92^{\mathrm{b}}$ & 84.42 & 4050 \\
46 & 75,333 & 25.00 & $71.58^{\mathrm{a}}$ & 84.75 & 4367 \\
92 & 67,926 & 24.67 & $70.58^{\mathrm{a}}$ & 76.42 & 3838 \\
138 & 70,593 & 23.33 & $71.42^{\mathrm{a}}$ & 79.42 & 4210 \\
LSD (0.05) & $\mathrm{NS}$ & $\mathrm{NS}$ & 1.542 & $\mathrm{NS}$ & $\mathrm{NS}$ \\
Trap crop & & & & & \\
Fallows & 72.444 & 23.33 & $67.17^{\mathrm{c}}$ & 81.50 & $3597^{\mathrm{b}}$ \\
Cowpea & 75.778 & 25.00 & $71.50^{\mathrm{a}}$ & 85.25 & $4999^{\mathrm{a}}$ \\
Soybean & 71.111 & 23.33 & $69.92^{\mathrm{b}}$ & 80.00 & $3861^{\mathrm{b}}$ \\
Desmodium & 69.556 & 24.33 & $68.92^{\mathrm{b}}$ & 78.25 & $4009^{\mathrm{b}}$ \\
LSD (0.05) & $\mathrm{NS}$ & $\mathrm{NS}$ & 1.542 & $\mathrm{NS}$ & 701.6 \\
CV (\%) & 13.1 & 11.1 & 2.7 & 13.1 & 20.5 \\
\hline
\end{tabular}

Means followed by the same letter(s) within a column are not significantly different at $\mathrm{P}=0.05, \mathrm{SCH}=$ stand count, TKW = thousand kernel weight, $\mathrm{KWH}=$ kernel weight per head, $\mathrm{NPP}^{-1}=$ number of panicle per plot, $\mathrm{HWP}^{-1}=$ Head Weight per plant.

application. Increasing the rate of nitrogen from 0 to $46 \mathrm{~kg} \mathrm{~N} \mathrm{ha}^{-1}$ increased kernel weight per head by $12 \%$ over the control (Table 4 ).

However, increasing the rate of nitrogen beyond $46 \mathrm{~kg} \mathrm{~N} \mathrm{ha}^{-1}$ did not increase the kernel weight per head. Low rainfall of the area may also have negative effect on nitrogen use by sorghum crop as the fate of $\mathrm{N}$ in the soil-plant system depends on climatic factors [29] [30]. The increased in grain weight due to application of nitrogen fertilizer from 0 to $46 \mathrm{~kg} \mathrm{~N} \mathrm{ha}^{-1}$ rates might be primarily due to increase in photosynthetic rate, which ultimately produce sufficient photosynthates available during grain development. The results are in conformity with the findings of [31] [32] who described that the higher partitioning of $\mathrm{N}$ into the reproductive parts for growth and development increased kernel weight per head.

The use of trap crops increased kernel weight per head especially with the use of cowpea. The kernel weight was significantly higher (71.50 g) with cowpea than soybean (69.92 g) and Desmodium (68.92 g) (Table 4). Significantly the lowest $(67.17 \mathrm{~g})$ kernel weight was recorded in fallow (no trap crops).Cowpea as trap crop gave $6 \%$ increase in kernel weight over the control. This result might be due to more release of exudates that stimulate Striga seed bank germination but that do not support its growth by cowpea that in return leads to reduction of the number of Striga which competes for the available nutrients thereby reducing the weight of kernel.

In agreement with this current result, [33] reported an increase in kernel 
weight per head in response to the use of trap crops due to the availability of low number of Striga that might have led to high kernel weight per head through facilitating leaf growth and photosynthetic activities, thereby increasing partitioning of assimilate to the storage organ.

\subsubsection{Thousand Kernel Weight (TKW)}

The main effect of nitrogen, trap crops and their interaction effects did not significantly affect thousand kernel weight of sorghum. Among treatments studied, there was variation in thousand kernel weight range from $23 \mathrm{~g}$ with use of $0 \mathrm{~N} \mathrm{~kg}$ $\mathrm{ha}^{-1}$ to $25 \mathrm{~g} 46 \mathrm{~N} \mathrm{~kg} \mathrm{ha}^{-1}$ and cowpea as a trap crop.

\subsubsection{Aboveground Dry Biomass Yield}

There was significant difference due to the main effects of trap crops and nitrogen $(P<0.05)$, but there was no difference due to interaction effect of treatments. Use of cowpea as trap crop gave the higher $\left(13,420 \mathrm{~kg} \mathrm{ha}^{-1}\right)$ biomass yield than the other trap crops (Table 5). Soybean and Desmodium had no significant variation with non-use of trap crops on biomass yield of sorghum. The biomass yield increased by about $33 \%$ over the control because of use of cowpea as trap crop. This result might be due to presence of lowest number of Striga under the cowpea trap crop plots that could reduce the biomass yield of sorghum through competition for nutrients and affected vegetative growth and leaf area index. In conformity with this result, [34] indicated that the effects of Striga resulted in a large reduction in host plant height, biomass, and eventual grain yield. Similarly, [35] reported that Striga establishes directly over the vascular system of the host

Table 5. Main effects of trap crops and nitrogen fertilizer application on the aboveground dry biomass yield (AGDBMY), grain yield and harvest index of sorghum at fedis in 2015 cropping season.

\begin{tabular}{cccc}
\hline Treatment & AGDBMY $\left(\mathrm{kg} \mathrm{ha}^{-1}\right)$ & Grain yield $\left(\mathrm{kg} \mathrm{ha}^{-1}\right)$ & Harvest index (\%) \\
\hline N-rate $\left(\mathrm{kg} \mathrm{ha}^{-1}\right)$ & & & \\
0 & $8536^{\mathrm{b}}$ & $2069^{\mathrm{c}}$ & 24.23 \\
46 & $12,746^{\mathrm{a}}$ & $3116^{\mathrm{a}}$ & 24.44 \\
92 & $11,201^{\mathrm{a}}$ & $2719^{\mathrm{b}}$ & 24.27 \\
138 & $11,755^{\mathrm{a}}$ & $2925^{\mathrm{ab}}$ & 24.88 \\
LSD (0.05) & 2481.4 & 335.1 & NS \\
Trap crop & & & \\
Fallow & $8883^{\mathrm{b}}$ & $2426^{\mathrm{b}}$ & 26.34 \\
Cowpea & $13,420^{\mathrm{a}}$ & $3157^{\mathrm{a}}$ & 23.52 \\
Soybean & $10,582^{\mathrm{b}}$ & $2660^{\mathrm{b}}$ & 25.13 \\
Desmodium & $11,353^{\mathrm{ab}}$ & $2586^{\mathrm{b}}$ & 22.77 \\
LSD (0.05) & 2481.4 & 335.1 & NS \\
CV (\%) & 26.9 & 14.8 & 33.7 \\
\hline
\end{tabular}

Means followed by the same letter(s) within a column are not significantly different at $\mathrm{P}=0.05$. 
plant, it drains out water and nutrients from the host resulting in $15 \%$ to $75 \%$ yield losses depending on the extent of infestation.

Analysis of variance (ANOVA) also indicated the highest (12,746 $\left.\mathrm{kg} \mathrm{ha}^{-1}\right)$ aboveground biomass yield with application of $46 \mathrm{~kg} \mathrm{~N} \mathrm{ha}^{-1}$ (Table 5). Though no significant difference was recorded across all $\mathrm{N}$ treatments, application of $46 \mathrm{~kg}$ $\mathrm{ha}^{-1}$ gave $33 \%$ biomass yield increase over the control. Therefore, the current results clearly depicted that due to nitrogen mobilization or mineralization and low uptake by crop under moisture stressed area, use of high level of nitrogen had no advantage on biomass yield. Nitrogen is a major yield-limiting nutrient in crop production under climatic condition of the study area in particular. The current result is in agreement with study that the fate of $\mathrm{N}$ in the soil-plant system depends on climatic factors [30] [31].

Leaf area and leaf photosynthetic rates are directly associated with plant dry matter production since light absorption by the leaves and changing it to assimilate are the other factors affecting the plant growth and production; the increase of leaf area in the farm increases the absorption of light, which ultimately increases the biomass yield. The highest LAI observed at high $\left(138 \mathrm{~kg} \mathrm{~N} \mathrm{ha}^{-1}\right)$ level of nitrogen indicated that more nitrogen assimilation into grain yield than biomass yield at high level of nitrogen but there was no significant difference in grain yield beyond the application of $46 \mathrm{~kg} \mathrm{~N} \mathrm{ha}^{-1}$ (Table 5). On the other hand, [36] reported that the application of $\mathrm{N}$ (as urea) at sowing and at tillering (total of $100 \mathrm{~kg} \mathrm{ha}^{-1}$ ) increased the sorghum aboveground biomass weight.

\subsubsection{Grain Yield $\left(\mathrm{kg} \mathrm{ha}^{-1}\right)$}

Result of data analysis (ANOVA) indicated highly significant $(\mathrm{P}<0.01)$ main effect of nitrogen rates and use of trap crops, while the interaction effect was not significant on grain yield. The grain yield increased with different level of nitrogen fertilizer application over the control. The highest $\left(3116 \mathrm{~kg} \mathrm{ha}^{-1}\right)$ grain yield was obtained with $46 \mathrm{~kg} \mathrm{~N} \mathrm{ha}^{-1}$ application, which was statistically at par with $138 \mathrm{~kg} \mathrm{~N} \mathrm{ha}^{-1}$ (2925 $\mathrm{kg} \mathrm{ha}^{-1}$ grain yield) application (Table 5). The yield increase with application of $46 \mathrm{~kg} \mathrm{~N} \mathrm{ha}^{-1}$ was by $33.6 \%$ over control. But there was no yield advantage beyond application of $46 \mathrm{~kg} \mathrm{~N} \mathrm{ha}^{-1}$ (Table 5). Likewise, the result clearly indicated that due to nitrogen mobilization or mineralization and low uptake by crop under moisture stressed area use of high level of nitrogen had no advantage on grain yield of sorghum. This yield increase might be due to the efficient use of $\mathrm{N}$ fertilizer by sorghum crop as well as from reduction of number of Striga due to $\mathrm{N}$ in sorghum crop. Similarly, higher leaf area index and kernel weight per head at the application of $46 \mathrm{~kg} \mathrm{~N} \mathrm{ha}^{-1}$ might have contributed to enhanced grain yield in this treatment. Therefore, the better grain yield was due to the positive effect of nitrogen, better absorption of light and increase of photosynthesis, plant growth rate, leaf area index and leaf area continuity and Striga reduction in the plots. This is concurrent with result stated as nitrogen suppresses some development stages of Striga such as stimulant production or activity [37] through increase in the osmotic pressure of host tissue and reduc- 
tion of osmotic pressure gradient towards the parasite and this reduction in osmotic pressure gradient decrease the ability of the parasite to survive.

The current finding is in agreement with the findings of [38] [39] who reported higher grain yield with increased levels of $\mathrm{N}$ from 0 to $150 \mathrm{~kg} \mathrm{ha}^{-1}$ in sorghum. Low soil fertility, particularly low nitrogen status, is conducive to Striga parasitism as reported by [40]. In split application of compound fertilizer where $20 \mathrm{~kg} \mathrm{~N} \mathrm{ha}^{-1}$ was applied during planting, a delayed in a seedling emergence of Striga was observed with higher crop vigour although supported higher Striga shoot count at later stage of the crop development than the control [41]. Other yield traits, like leaf area index, might also have effect on grain yield increments, which was described as sorghum grain yield is closely related to green leaf area, [42] and leaf photosynthetic rates, [43] [44].

Analysis of variance depicted that the highest $\left(3157 \mathrm{~kg} \mathrm{ha}^{-1}\right)$ grain yield was obtained by the use of cowpea as trap crop but the two trap crops had no significant variation from the control (Table 5). The enhanced grain yield with use of cowpea might be due to the increase in the yield attributing characters and nutrient uptake of the crop as well as reduction in Striga seed bank. With use of cowpea, the grain yield increased by $23 \%$ over control. This result clearly indicated that cowpea had more profound effect on striga reduction or suppresses through more suicidal release than the control. These results are in agreement with observations of [27] who reported higher root exudates production or stimulant concentration resulted in case of cowpea as trap crop. Cowpea cultivars reduced Striga emergence by $40 \%$ as reported by [45]. that the trap crops, such as cowpea, induced Striga seed germination but did not support its subsequent growth and in the absence of a suitable host, the Striga seedling died within four days from germination observed by [46]. Similarly, the use of legume crops also helps to add nitrogen to soil and hasten nutrient transformation. These results were in line with earlier studies of [47], which showed that the addition of a legume in the sequence resulted in higher yield and profitability. Inclusion of legumes in the rotation hastened the $\mathrm{N}$ and $\mathrm{P}$ transformation [48] [49] and also increased root growth and $\mathrm{N}$ use efficiency of cereal crops, resulting in greater productivity of cereal-based production system [50] [51].

In line with results of this current study, [52] indicated that one season cowpea had a positive effect on subsequent millet grain yields, soil organic carbon and nitrogen, and reduced Striga infestation. The increase in yields due to millet-cowpea rotation was $37 \%$ compared to 3 - 5 years continuous millet cropping.

\subsubsection{Harvest Index (HI)}

For grain crops, harvest index (\%) is the ratio of harvested grain to total aboveground dry biomass and this can be used as a measure of reproductive efficiency. However, in this study neither the main effects of nitrogen and the trap crops nor their interaction effects had significant effect on harvest index of sorghum. Among the treatments studied, there was variation in harvest index range from 
$22.77 \%$ with use of Desmodium to $26.34 \%$ with fallow (no trap crop).

\section{Summary and Conclusion}

Striga hermonthica is difficult to manage effectively because most of its damage to the host plant occurs underground before the parasitic plant emerges and causes serious threat to cultivation of sorghum in areas of insufficient and ill distributed rainfall, and poor soil fertility.

Therefore, to reduce yield losses and severity of Striga, a field experiment was conducted on heavily Striga infested field in Fedis district, Boko site in 2015 cropping season to determine the effect of trap crops (cowpea, soybean, Desmodium and control) and $\mathrm{N}$ fertilizer rates $\left(0,46,92\right.$ and $\left.138 \mathrm{~kg} \mathrm{~N} \mathrm{ha}^{-1}\right)$ on management of Striga, yield related traits and yield of sorghum. The experiment was laid out in a factorial arrangement in a randomized complete block design (RCBD) with three replications. In this study the use of integrated Striga management showed significant effect.

Therefore, it can be tentatively concluded that use of cowpea as trap crop in combination with $46 \mathrm{~kg} \mathrm{~N} \mathrm{ha}^{-1}$ is a promising treatment to reduce Striga seed bank and to increase sorghum yield and had economic benefit. However, to draw a conclusive recommendation, the experiment needs to be repeated over years and locations.

\section{Acknowledgements}

First and foremost, I thank the Almighty GOD for blessing me abundantly and providing me with everything I needed throughout my study. I would like to extend my sincere gratitude and deepest appreciation to, Prof. Tamado Tana, for his consistent and stimulating advice, proper guidance during the fieldwork and data collections, critical reading of the manuscript and valuable suggestions. My special thanks also go to Dr. Jemal Abdullahi, for his utmost co-operation and assistance during the research work.

I would like to express my thanks to Mr. Alemayehu Birri and Fuad Abduselam for their technical support during data collection. I would also like to extend many thanks to Amsalu Wagari, Adane Ashebir for their support during data collection and to office staff members for providing me with the necessary materials and gadgets. A deep gratitude is extended to Oromia Agricultural Research Institute (OARI) for the financial support it provided me for the research work.

\section{References}

[1] CSA (Central Statistical Authority) (2015) Agricultural Sample Survey Report on Area and Production of Major Crops for Ruralprivate Peasant Holdings. Statistical Bulletin, 388, Addis Ababa.

[2] Firew, M. (2006) Farmer and Formal Breeding of Sorghum [Sorghum bicolor (L.) Moench] and the Implicationsfor Integrated Plant Breeding. Euphytica, 152, 163-176. https://doi.org/10.1007/s10681-006-9191-7

[3] MARC (Melkassa Agricultural Research Center) (2010) Progress Report for 
2004-2010. EARO, Ethiopia.

[4] Wortmann, C.S., Mamo, M., Abebe, G., Mburu, C., Kayuki, K.C., Letayo, E. and Xerinda, S. (2006) The Atlas of Sorghum Production in Five Countries of Eastern Africa. University of Nebraska, Lincoln, USA.

[5] MoARD (Federal Ministry of Agriculture and Development of Ethiopia) (2002) Animal and Plant Health Regulatory Directorate. Crop Variety Register Issue No. 02. HY international printing Enterprises, Addis Ababa, Ethiopia.

[6] GenStat (2012) GenStat for Windows. Fifteenth Edition. VSN International Ltd., Oxford.

[7] Gomez, K.A. and Gomez, A.A. (1984) Statistical Procedures for Agricultural Research. 2nd Edition, John Wiley and Sons, New York, 680 p.

[8] Onwueme, I.C. and Sinha, T.D. (1991) Field Crop Production in Tropical Africa. CTA. Wageningen, the Netherlands.

[9] Tekalign, T. (1991) Soil, Plant, Water, Fertilizer, Animal Manure and Compost Analysis. Working Document No. 13. International Livestock Research Center for Africa, Addis Ababa.

[10] Cottenie, A. (1980) Soil and Plant Testing as a Basis of Fertilizer Recommendations. FAO Soil Bulletin 38/2. Food and Agriculture Organization of the United Nations, Rome.

[11] Debele, B. (1980) The Physical Criteria and Their Rating Proposed for Land Evaluation in the Highland Region of Ethiopia. Land Use Planning and Regulatory Department, Ministry of Agriculture, Addis Ababa, Ethiopia.

[12] Booker (1991) Tropical Soil Manual, London.

[13] Nigussie, M., Girma, A., Anchala, C. and Kirub, A., Eds. (2009) Improved Technologies and Resource Management for Ethiopian Agriculture. A Training Manual, RCBP MoARD, Addis Ababa, Ethiopia.

[14] Manna, M.C., Swarup, A., Wanjari, R.H., Ravankar, H.N., Mishra, B., Saha, M.N., Singh, Y.V., Sahi, D.K. and Sarap, P.A. (2005) Long-Term Effect of Fertilizer and Manure Application on Soil Organic Carbon Storage, Soil Quality and Yield Sustainability under Sub-Humid and Semi-Arid Tropical India. Field Crops Research, 93, 264-280. https://doi.org/10.1016/j.fcr.2004.10.006

[15] Frederick, J.R. and Camberato, J.J. (1995) Water and Nitrogen Effects on Winter Wheat in the Southeastern Coastal Plain: II. Physiological Response. Journal of Agronomy, 87, 527-532. https://doi.org/10.2134/agronj1995.00021962008700030022x

[16] Deldon, A.V. (2001) Yield and Growth Components of Potato and Wheat under Organic Nitrogen Management. Journal of Agronomy, 93, 1370-1385. https://doi.org/10.2134/agronj2001.1370

[17] Samuel, T., Birhanu, A., Amsalu, A., Asrat, Z., Alemayehu, B., Gabisa, B., Solomon, A. and Fikadu, T. (2013) Efforts towards Solving the Disastrous Effect of Extreme Striga hermonthica Infestation and Shortage of Rain on Sorghum Production in the Lowlands of Eastern Ethiopia. American Journal of Agricultural Research, 1, 1-15. http://www.scitecpub.com/Journals.php

[18] Gobeze, L. (1999) Effect of Special Arrangement and Nitrogen Fertilizer Application on (Sorghum bicolor L. Moench) and Ground Nut (Arachis hypogaea L.) Intercrop System in Eastern Ethiopia. MSc Thesis, Haramaya University of Agriculture, Haramaya.

[19] Gupta, R.P. and Sharma, V.P. (2000) Effect of Different Spacing and Levels of Ni- 
trogen for Production of Export of Quality Onion Bulbs Planted on Raised Beds. News Letter National Horticultural Research and Development Foundation, 20, 13-16.

[20] Sineba, W. and Drennon, D.S.H. (2001) Vegetative Growth of Sorghum and Striga hermonthica in Response to Nitrogen and the Degree of Host Root Infection. European Journal of Plant Pathology, 107, 849-860. https://doi.org/10.1023/A:1013150108056

[21] Frost, D.L., Gurney, A.L., Press, M.C. and Scholes, J.D. (1997) Striga hermonthica Reduces Photosynthesis in Sorghum: The Importance of Stomatal Limitations and a Potential Role for ABA. Plant Cell Environment, 20, 483-492. https://doi.org/10.1046/j.1365-3040.1997.d01-87.x

[22] Gebremariam, G. and Assefa, D. (2015) Nitrogen Fertilization Effect on Grain Sorghum [Sorghum bicolor (L.) Moench] Yield, Yield Components and Witchweed (Striga hermonthica (Del.) Benth) Infestation in Northern Ethiopia. International Journal of Agricultural Research, 10, 14-23.

[23] Maan, A.A.S., Wright, D. and Alcock, M.B. (1989) Effects of Sowing Date, Sowing Density and Nitrogen Supply on Leaf Extension in Spring Barley. Journal of Agricultural Science, 113, 305-315.

[24] Mustafa, H.A. (1995) Effect of Nitrogen Fertilizer Dose and Time of Application on the Growth and Yield of Four Sorghum Hybrids. M.Sc. Thesis, University of Khartoum, Faculty of Agriculture, Khartoum State.

[25] Sarmiso, Z. (2015) Effect of Nitrogen Fertilizer on Striga Infestation, Yield and Yield Related Traits in Sorghum [Sorghum bicolor (L.) Moench] Varieties at Kile, Eastern Ethiopia. M.Sc. Thesis, Haramaya University, Haramaya.

[26] Miko, S. and Manga, A.A. (2008) Effect of Intra-Spacing and Nitrogen Rates on Growth Yield of Sorghum (Sorghum bicolor (L.)) Var. ICSV 400. Production Agriculture and Technology, 4, 66-73.

[27] Hosamani, M.B. (1985) Studies on Control of Orobanche (Orobanche cernua Loefl.) and Striga (Striga asiatica (L.) Kuntze) by Trap Crops. M.Sc. Agriculture Thesis, University of Agricultural Science, Dharwad.

[28] Botanga, C.J., Alabi, S.O., Echekwu, C.A. and Lagoke, S.T.O. (2003) Genetics of Suicidal Germination of Striga hertmonthica (Del.) Benth by Cotton. Crop Science, 43, 483-488. https://doi.org/10.2135/cropsci2003.0483

[29] Sieling, K., Schröder, H., Finck, M. and Hanus, H. (1998) Yield, N Uptake, and Apparent N-Use Efficiency of Winter Wheat and Winter Barley Grown in Different Cropping Systems. Journal of Agricultural Science, 131, 375-387. https://doi.org/10.1017/S0021859698005838

[30] Malhi, S.S., Grant, C.A., Johnston, A.M. and Gill, K.S. (2001) Nitrogen Fertilization Management for No-Till Cereal Production in the Canadian Great Plains: A Review. Soil Tillage Research, 60, 101-122. https://doi.org/10.1016/S0167-1987(01)00176-3

[31] Guled, M.B. (1982) Effect of Manuring and 2.4-D on Striga Control in Sorghum. M.Sc. Agricultural Thesis, University of Agricultural Science, Dharwad.

[32] Showemimo, F.A. (2002) Evaluation of Sorghum Lines for Striga Resistance. Tropical Agriculture, 79, 237-240.

[33] Kler, F., Sharma, C.R. and Sharma, J. (2007) Effect of Rock Phosphate Enriched FYM on Wheat (Triticum aestivum L.)-Rice (Oryza sativa L.) Cropping Sequence in Acid Alfisol. Himachal Journal of Agriculture Research, 25, 13-18. 
[34] Gurney, A.L., Press, M.C. and Scholes, J.D. (1999) Infection Time and Density Influence the Response of Sorghum to the Parasitic Angiosperm Striga hermonthica. New Phytologist, 143, 573-580. https://doi.org/10.1046/j.1469-8137.1999.00467.x

[35] Oswald, A. and Ransom, J.K. (2001) Striga Control and Improved Farm Productivity using Crop Rotation. Crop Protection, 20, 113-120. https://doi.org/10.1016/S0261-2194(00)00063-6

[36] Hess, D.E. and Gebisa, E. (1987) Effect of Cultural Treatments on Infestation of Striga hermonthica (Del.) Benth. on Sorghum in Niger. Proceedings of the 4 th International Symposium on Parasitic Flowering Plants, Marburg, 8-12 August 1987, 376-375.

[37] Cechin, I. and Press, M.C. (1993) Nitrogen Relations of the Sorghum Striga hermonthica Host Parasite Association-Germination, Attachment and Early Growth. New Phytologist, 124, 681-687. https://doi.org/10.1111/j.1469-8137.1993.tb03858.x

[38] Akdeniz, H., Yilmaz, I., Bozkurt, M.A. and Keskin, B. (2006) The Effects of Sewage Sludge and Nitrogen Applications on Grain Sorghum Grown (Sorghum vulgare L.) in Van, Turkey. Polish Journal of Environmental Studies, 15, 19-26.

[39] Poornima, S., Geethalakshmi, V. and Leelamathi, R.M. (2008) Effect of Sowing Dates and Nitrogen Levels on Yield and Juice Quality of Sweet Sorghum. Journal of Agricultural Biological Science, 4, 651-654.

[40] Doggett, H. (1965) Striga hermonthica on Sorghum in East Africa. East African Agricultural Journal, 18, 155-159. https://doi.org/10.1080/03670074.1953.11664856

[41] Isah, K.M. (2002) Management of Striga hermonthica (Del.) Benth as Influenced by Maize Variety and Spacing, Split Application of Compound Fertilizer and Legume Intercrop. M.Sc. Thesis, Department of Crop Production and Crop Protection, University of Agriculture, Abeokuta, $189 \mathrm{p}$.

[42] Borrel, A.K. and Douglas, A.C.L. (1997) Maintaining Green Leaf Area in Grain Sorghum Increased Nitrogen Uptake under Post-Anthesis Drought. International Sorghum and Millets Newsletter, 38, 89-91.

[43] Locke, M.A. and Hons, F.M. (1988) Effect of N Rate and Tillage on Yield, N Accumulation and Leaf N Concentration of Sorghum. Soil Tillage Research, 12, 223-233. https://doi.org/10.1016/0167-1987(88)90013-X

[44] Peng, S., Kreig, D.R. and Girma, F.S. (1991) Leaf Photosynthetic Rates Correlation with Biomass and Grain Production in Grain Sorghum Lines. Photosynthesis Research, 28, 1-7. https://doi.org/10.1007/BF00027171

[45] Chivinge, O.A., Kasamble, E., Mariga, I.K. and Mabasa, S. (2001) Suppressive Effect of Cowpea Cultivars on Wichweed in Maize/Cowpea Intercrop and Yield Performance of Maize. African Crop Science Conference Proceedings, 5, 135-140.

[46] Gebisa, E., Butler, L.G. and Babiker, A.G.T. (1993) New Approaches to the Control of Striga Research at Purdue University. Agricultural Experiment Station, Purdue University, West Lafayette, $27 \mathrm{p}$.

[47] Singh, Y., Chaudhary, D.C., Singh, S.P., Bhardwaj, A.K. and Singh, D. (1996) Sustainability of Rice-Wheat Sequential Cropping through Introduction of Legume Crops and Green Manure Crop in the System. Indian Journal of Agronomy, 41, 510-514.

[48] Wani, S.P., Rupela, O.P. and Lee, K.K. (1995) Sustainable Agriculture in the Semi-Arid Tropics through Bilogical Nitrogen Fixation in Grain Legumes. Plant Soil, 174, 29-49. https://doi.org/10.1007/BF00032240

[49] Kannaiyan, S. (2000) Integrated Nutrient Management Strategies in Wetland Rice 
Eco-System. In: Kannaiyan, S., Thiyagarajan, T.M., Mathan, K.K., Savithiri, P., Selvakumari, G. and Murugappan, V., Eds., Theme Papers on Integrated Nutrient Management, Tamil NaduAgricultural University, and Department of Agriculture, Tamil Nadu, 1-20.

[50] Buresh, R.J. and De Datta, S.K. (1991) Nitrogen Dynamics and Management in Rice-Legume Cropping Systems. Advanced Agronomy, 45, 1-59. https://doi.org/10.1016/S0065-2113(08)60037-1

[51] Yadav, R.L., Dwivedi, B.S., Gangwar, K.S. and Prasad, K. (1998) Overview and Prospects for Enhancingresidual Benefits of Legumes in the Rice and Wheat Cropping Systems in India. In: Kumar Rao, J.V.D.K., Johansen, C. and Rego, T.J., Eds., Residual Effects of Legumes in Rice and Wheat Cropping Systems of Indo-Gangetic Plain Patancheru, International Crops Research Institute for the Semi-Arid Tropics, 207-225.

[52] Samake, O. (2003) Integrated Crop Management Strategies with Sahelian Land Use Systems to Improve Agricultural Productivity and Sustainability. A Case Study in Malawi. Dissertation No. 345, Wageningen University, Wageningen. 